\title{
Colonisation and its Role in Supply Networks of Silver: The Coinages of Apollonia and Dyrrhachium/Epidamnos (Illyria)
}

\author{
KATRIN JULIA WESTNER ${ }^{1}$, FRANCIS ALBARÈDE ${ }^{2}$ AND \\ JANNE BLICHERT-TOFT ${ }^{1}$ \\ ${ }^{1}$ Ecole Normale Supérieure de Lyon \\ ${ }^{2}$ Ecole Normale Superieure de Lyon \\ Presenting Author: katrin.westner@ens-lyon.fr
}

The large-scaled spread of coin use in the Mediterranean from the $6^{\text {th }}-5^{\text {th }}$ centuries BCE on created an unprecedented need for silver and firmly established supra-regional links between financial and political power. Gaining access to silver - or depriving rivalling civilisations thereof - incited territorial expansion and colonial (trade) contacts with indigenous peoples, associating monetization with wide-ranging societal, economic, and cultural transformations reaching far beyond the borders of the Greco-Roman world.

Here, we present a dataset (compositional and $\mathrm{Pb}-\mathrm{Ag}$ isotopic data) centered on silver coinages from the cities of Apollonia and Dyrrhachium/Epidamnos in Illyria (modern-day Albania), which were favourably located along major sea passages in the eastern Mediterranean (to Italy and the Greek mainland) and at terminal points of inland routes. Apollonia's and Dyrrhachium's minting activity (c. $5^{\text {th }}-1^{\text {st }}$ centuries BCE) spans from their foundation as Greek colonies to their time as Roman protectorates, with the largest output of currency from c. 120/100 BCE to the middle of the $1^{\text {st }}$ century BCE falling into the period of Rome's military campaigns in the eastern Balkans [1]. Our preliminary analyses show that the cities were (largely) independent of bullion supplies from their parental city Corinth, and later the Roman Republic. Instead, the data strongly suggests that they exported silver from the Balkans, including regions in the interior inhabited by indigenous communities, and contributed this metal to the antique silver stock in form of their coins. These results have important implications for the role of Apollonia's and Dyrrhachium's coinages in the supply and cycling of silver metal at and across the Balkan Peninsula and their function in the politics of the Greco-Roman world, particularly in the expansional campaigns of the later Roman Republic. Furthermore, our findings shed new light on colonisation as a possible strategy to access silver as well as the potential existence and nature of trade networks with indigenous communities outside the borders of the Greco-Roman world, where Apollonia and Dyrrhachium as Greek cultural centers could have served as gateways for the monetization of peripheral regions.

[1] Meta (2012). Revue Belge de Numismatique et Sigillographie 158, 21-38. 